\title{
Comparison of Accelerated Resolution Therapy (ART) for Post-Traumatic Stress Disorder (PTSD) Between Veterans With and Without Prior PTSD Treatment
}

Tiantian Pang ${ }^{\mathrm{a}}$, Lindsay Murn ${ }^{\mathrm{b}}$, Dana Williams ${ }^{\mathrm{a}}$, Maayan Lawental ${ }^{\mathrm{a}}$, Anya Abhayakumar ${ }^{\mathrm{c}}$, and

\author{
Kevin E. Kip ${ }^{d}$ \\ ${ }^{a}$ University of South Florida, Tampa, FL, USA \\ ${ }^{b}$ Minnesota State University, Mankato, Mankato, MN, USA \\ ${ }^{\mathrm{c} C a r y}$ Academy, Cary, NC, USA \\ ${ }^{\mathrm{d} U n i v e r s i t y ~ o f ~ P i t t s b u r g h ~ M e d i c a l ~ C e n t e r, ~ P i t t s b u r g h, ~ P A, ~ U S A ~}$
}

*Correspondence: Tiantian Pang; Email: tiantianp@usf.edu; University of South Florida, Tampa, FL, USA

\section{ORCID}

Tiantian Pang https://orcid.org/0000-0002-0749-1450

Dana Williams https://orcid.org/0000-0002-8450-0031

Kevin E. Kip https://orcid.org/0000-0002-6401-0051 
medRxiv preprint doi: https://doi.org/10.1101/2021.04.15.21255572; this version posted April 17, 2021. The copyright holder for this preprint (which was not certified by peer review) is the author/funder, who has granted medRxiv a license to display the preprint in perpetuity.

All rights reserved. No reuse allowed without permission.

\begin{abstract}
Background: Post-traumatic stress disorder (PTSD) is a psychiatric disorder commonly caused by a traumatic event(s) and prevalent among service members and veterans. Accelerated Resolution Therapy (ART) is an emerging "mind-body" psychotherapy for PTSD that is generally briefer and less expensive than current first-line treatments, such as cognitive processing therapy (CPT) and prolonged exposure (PE) therapy.
\end{abstract}

Objective: This study aimed to examine the results of ART for treatment of military-related PTSD, with stratification by prior history of PTSD treatment, including refractory PTSD following receipt of guideline-driven first-line psychotherapy.

Methods: The study compares the PTSD treatment results of ART between (military service members and/or) veterans with a prior history of PTSD treatment (medication only, $\mathrm{n}=40$; firstline psychotherapy, $n=33$; other psychotherapy, $n=42)$ and a treatment-naïve group ( $n=33)$. Participants were assessed at baseline, post-treatment, and 3- or 6-month follow-up using PCL-M scores (PTSD checklist).

Results: Mean age was 43.8 years, $95 \%$ male, $84 \%$ white race. The treatment completion rate was $72 \%$ with a mean of 3.5 treatment sessions. Within-group standardized effect sizes for preto-post changes in PTSD scores (PCL-M) were large at 1.11, 1.88, 1.03, and 1.48 for the medication only, first-line psychotherapy, other psychotherapy, and treatment-naïve groups, respectively ( $\mathrm{p}=0.02$ for between-group comparison). Similar results were observed for measures of depression and anxiety, and baseline to follow-up results was generally similar.

Conclusions: In a brief treatment period, ART appears to result in substantial reductions in symptoms of PTSD among veterans, including those previously treated (unsuccessfully) with first-line psychotherapies endorsed by the U.S. Department of Defense (DoD) and Veterans 
medRxiv preprint doi: https://doi.org/10.1101/2021.04.15.21255572; this version posted April 17, 2021. The copyright holder for this preprint (which was not certified by peer review) is the author/funder, who has granted medRxiv a license to display the preprint in perpetuity. All rights reserved. No reuse allowed without permission.

Affairs (VA). These results suggest that ART be considered as a treatment modality for veterans with refractory PTSD.

Keyword(s): Military, post-traumatic stress disorder, psychological trauma, veterans, eye movements, brief treatment, refractory PTSD

Highlights: Accelerated Resolution Therapy (ART) is a potentially acceptable psychological intervention for treatment-refractory PTSD. 
medRxiv preprint doi: https://doi.org/10.1101/2021.04.15.21255572; this version posted April 17, 2021. The copyright holder for this preprint (which was not certified by peer review) is the author/funder, who has granted medRxiv a license to display the preprint in perpetuity.

All rights reserved. No reuse allowed without permission.

\section{Introduction}

Trauma is ubiquitous. A traumatic event is an experience that is shocking, scary, dangerous, and/or life-threatening (including but not limited to a natural disaster, serious accident or injury, physical abuse, sexual or intimate partner violence, terroristic attacks, or military or combat experience) (American Psychiatric Association, 2020; National Center for PTSD, 2019; National Institude of Mental Health, 2019). Nearly two-thirds of adults have encountered a traumatic or adverse incident during childhood, and 50-60\% of adult men and women have experienced at least one trauma in their lifetime, with between $10-20 \%$ developing post-traumatic stress disorder (Centers for Disease Control and Prevention, 2020; National Center for PTSD, 2019; U.S. Department of Veterans Affairs, 2019). Post-traumatic stress disorder (PTSD) is a chronic, disabling, and stress-related psychiatric disorder that may occur after exposure to traumatic events(s) and may result in persistent re-experiencing of details related to the trauma(s), avoidance symptoms, negative alterations in cognitions and mood, and alterations in trauma-related arousal and reactivity (American Psychiatric Association, 2013). PTSD rates are particularly high among U.S. military service members and veterans and are accompanied by an increased risk for other mental health concerns like depression, substance misuse, and even suicide (U.S. Department of Veterans Affairs, 2021). As of 2019, there are 17 million military veterans in the United States with $35.6 \%$ from the Vietnam era, $22 \%$ from the Gulf War (8/1990-8/2001), 21.7\% from the post-911 era (9/2001 or later), 6.6\% from the Korean War, and 2.2\% from World War II (United States Census Bureau, 2019). In 2017, there were nearly 1.3 million active military personnel and 809,000 reserve forces (Department of Defense, 2017). Among the military personnel who had a recent deployment to Iraq and Afghanistan, the prevalence of PTSD has been estimated at 10-20\% (Gates et al., 2012; Kok, et al., 2012; 
medRxiv preprint doi: https://doi.org/10.1101/2021.04.15.21255572; this version posted April 17, 2021. The copyright holder for this preprint (which was not certified by peer review) is the author/funder, who has granted medRxiv a license to display the preprint in perpetuity.

All rights reserved. No reuse allowed without permission.

Ramchand et al., 2010). A recent longitudinal cohort study found that at least $50 \%$ of U.S.

service members and veterans suffered from persistent PTSD symptoms and impairment at threeyear follow-up; of those, 71\% still met criteria six years later (Armenta et al., 2018). Moreover, approximately $11 \%$ of Vietnam War veterans experience persistent PTSD-related impairment (Marmar et al., 2015). The increased risk of PTSD in military personnel is associated with a longer cumulative length of deployments, combat-related exposure, disabling injury/illness, and depression (Armenta et al., 2018; Xue et al., 2015). The large number of military personnel in the U.S. with debilitating PTSD illustrates a paramount interest and need for effective treatments. Untreated and/or inadequately treated PTSD can cause distress and lead to a series of healthrelated comorbidities and interfere with social, educational, and occupational functioning (Bryan et al., 2015; Levine et al., 2014; National Collaborating Centre for Mental Health (UK), 2005; Pietrzak et al., 2011; Wisco et al., 2014).

The VA/DoD Clinical Practice Guideline recommends the use of individual, manualized, trauma-focused psychotherapy for PTSD that has a primary exposure and/or cognitive restructuring intervention (The Management of Posttraumatic Stress Disorder Work Group, 2017). The most well-established "first-line" treatments for PTSD are Cognitive Process Therapy (CPT), Prolonged Exposure (PE) Therapy, and Eye Movement Desensitization and Reprocessing (EMDR) (American Psychological Association, 2017; Cusack et al., 2016; Hamblen et al., 2019; The Management of Posttraumatic Stress Disorder Work Group, 2017; Watts et al., 2013). Unfortunately, clinical response and treatment completion rates with first-line psychotherapies for PTSD - PE and CPT in particular - have been suboptimal. In brief, a review of first-line psychotherapy for military-related PTSD literature included four randomized controlled trials (RCTs) examining PE and five examining CPT reported that clinical outcomes were 
medRxiv preprint doi: https://doi.org/10.1101/2021.04.15.21255572; this version posted April 17, 2021. The copyright holder for this preprint (which was not certified by peer review) is the author/funder, who has granted medRxiv a license to display the preprint in perpetuity.

All rights reserved. No reuse allowed without permission.

heterogeneous, nonresponse rates were high, and the benefit of PE and CPT relative to nontrauma-focused treatments was small (Steenkamp et al., 2015). More recent trials of PTSD treatment have had a greater emphasis on combat exposure instead of sexual trauma, used active comparison groups, and examined active-duty personnel treated in-garrison, rather than only veterans (Foa et al., 2018; Nidich et al., 2018; Rauch et al., 2019; Resick et al., 2017; Resick et al., 2015). Across these trials, all active treatments (PE, CPT, present-centered therapy, sertraline, and transcendental meditation) reduced PTSD symptoms, though nonresponse rates were high, and the types of treatment did not significantly differ in their outcomes (Foa et al., 2018; Nidich et al., 2018; Rauch et al., 2019; Resick et al., 2017; Resick et al., 2015; Steenkamp et al., 2020). Overall, the treatment effect was modest at most, with $50 \%$ or less of patients assigned to PE experiencing recovery or improvement, and the diagnosis often retained posttreatment, indicating that symptoms improved yet rarely remitted (Foa et al., 2018; Nidich et al., 2018; Rauch et al., 2019; Resick et al., 2017; Steenkamp et al., 2020). Moreover, trials of PE that included standard length of therapy (e.g., 8 weeks) reported treatment non-completion rates of 25\% to 48\% (Foa et al., 2018; Nidich et al., 2018; Rauch et al., 2019). Thus, Steenkamp et al. (2020) concluded that current first-line psychotherapies have limited efficacy in treating military-related PTSD and do not outperform non-trauma-focused interventions.

Accelerated Resolution Therapy (ART) is an emerging "mind-body" psychotherapy that is considered an alternative treatment for PTSD. Unlike current first-line psychotherapies, ART is short-term - typically delivered in 1-5 sessions over an approximate two-week timeframe. Furthermore, ART does not require additional therapeutic homework or medication, which reduces patient time (and financial) commitment when compared to the 8-15 sessions recommended for PE, CPT, and EMDR protocols (Kip et al., 2012). ART has shown effective 
medRxiv preprint doi: https://doi.org/10.1101/2021.04.15.21255572; this version posted April 17, 2021. The copyright holder for this preprint (which was not certified by peer review) is the author/funder, who has granted medRxiv a license to display the preprint in perpetuity.

All rights reserved. No reuse allowed without permission.

reduction in PTSD symptoms in adult civilian and military populations within an average of four treatment sessions with a completion rate of approximately 90\% (Kip et al., 2012; Kip et al., 2015; Kip et al., 2013). In addition, ART does not require verbalization of the traumatic event, which may be particularly beneficial for military personnel who cannot share the confidential and sensitive details of the events (Kip et al., 2013), or for those who are reticent to do so, as is required in the more emotionally-demanding therapies like CPT and PE (Steenkamp et al., 2020). Therefore, the treatment protocol of ART may address some of the limitations of the current first-line psychotherapies. ART has a solid theoretical basis (Kip et al., 2014; Kip \& Diamond, 2018) and is a promising approach for consideration as an effective trauma-focused treatment modality to meet the specific needs of military service members and veterans who have either never received treatment and or who have treatment-refractory PTSD (Kip et al., 2019; Kip \& Diamond, 2018). Thus, the present analysis examines the results of ART used in the treatment of military-related PTSD, with stratification by prior PTSD treatment history, including refractory PTSD following receipt of first-line recommended psychotherapy.

\section{Method}

Two published studies have been conducted on Accelerated Resolution Therapy (ART) for treatment of post-traumatic stress disorder (PTSD) in U.S. military service members and veterans to serve as the basis for this analysis. The first study was an uncontrolled observational prospective cohort study $(n=188)$, with clinical assessment performed at baseline, post-treatment, and 6-month follow-up (Kip et al., 2016). Of the 188 screened participants, 148 met the inclusion criteria and initiated treatment with ART. The second study was a two-group randomized controlled trial ( $n=63$; Kip et al., 2013). A total of 57 service members or veterans were eligible and enrolled, of whom, 28 out of 29 participants received the ART intervention, and 22 out of 28 
medRxiv preprint doi: https://doi.org/10.1101/2021.04.15.21255572; this version posted April 17, 2021. The copyright holder for this preprint (which was not certified by peer review) is the author/funder, who has granted medRxiv a license to display the preprint in perpetuity.

All rights reserved. No reuse allowed without permission.

subjects from the control group crossed over to receive ART after three months. In total, 50 participants completed the treatment with ART and were assessed with clinical measurements at baseline and post-treatment, and a subset at 3-month follow-up. Similar inclusion and exclusion criteria were used for enrollment, and the screening instrument and recruitment methods were generally similar between the two previously published studies (Kip et al., 2016; Kip et al., 2013). Both studies were approved by the Institutional Review Board at University of South Florida (USF) and all participants provided written informed consent. The present study combined the two data sets for more in-depth analyses.

Demographic, brief medical history, and prior history of PTSD treatment data were collected at baseline. Both studies used similar outcome measures to assess the pre-to-post changes in symptoms of PTSD and its associated comorbidities: the 17-item military version of the PTSD Checklist (PCL-M) (Blanchard et al., 1996; Weathers et al., 1993), the 20-item Center for Epidemiologic Studies Depression Scale (CES-D) for depression (Radloff, 1977); the 21-item State-Trait Inventory for Cognitive and Somatic Anxiety (STICSA) for anxiety (Grös et al., 2007); the 18-item Brief Symptom Inventory (BSI) for psychological distress (Meachen et al., 2008); and the Pittsburgh Sleep Quality Index (PSQI) for sleep quality (Buysse et al., 1989).

\section{Definitions for Parallel Previous PTSD Treatment History}

For the classification of prior PTSD treatment for analysis, two methods were used. First, classification \#1 included only participants from the prospective cohort study (Kip et al., 2016). This study included specific documentation on the prior type(s) of psychotherapy received by service members/veterans for treatment of PTSD. This allowed classification of prior "first-line" evidence-based psychotherapy received, particularly prolonged exposure (PE) and/or cognitive processing therapy (CPT). With this information, U.S. military service members/veterans were 
medRxiv preprint doi: https://doi.org/10.1101/2021.04.15.21255572; this version posted April 17, 2021. The copyright holder for this preprint

grouped based on types of prior history of PTSD treatment, as follows: treatment-naïve $(n=33)$, medication only $(n=40)$, other types of psychotherapy $(n=42)$, or first-line psychotherapy $(n=33)$. The last three groups were defined as treatment-refractory because study participants reported receiving prior treatment(s) for PTSD, yet were highly symptomatic at the time of assessment for ART.

For the second classification (classification \#2), a larger sample was constructed by pooling data from the prospective cohort study and randomized controlled trial, described above (Kip et al., 2013; Kip et al., 2016), yet without the granularity of knowing the specific types of psychotherapy received among all participants. This resulted in study participants being classified into four groups based on their prior history of PTSD treatment, as follows: treatmentnaïve $(n=50)$, medication only $(n=43)$, psychotherapy $(n=25)$, or psychotherapy and medication $(n=80)$.

\section{ART Intervention}

For both studies, ART was delivered in 1 to 5 treatment sessions with a typical session duration of 60 to 75 minutes. In brief, each session consisted of two core components of traumafocused therapy - imaginal exposure (IE) and imaginary rescripting (IR) - facilitated with the use of sets of bilateral (side-to-side) eye movements. The bilateral eye movements were performed throughout the treatment session by having the participant follow the ART clinician's oscillating hand, silently moving their eyes from right to left horizontally, with a fixed number of 40 bilateral eye movements per set.

In the IE phase, participants were asked to recall the traumatic event(s) or scene, with a focus on identifying the somatic, emotional, and physiological sensations that emerged. Each sensation was identified by the participant to the clinician, who instructed the participant to 
medRxiv preprint doi: https://doi.org/10.1101/2021.04.15.21255572; this version posted April 17, 2021. The copyright holder for this preprint (which was not certified by peer review) is the author/funder, who has granted medRxiv a license to display the preprint in perpetuity.

All rights reserved. No reuse allowed without permission.

notice (focus on) the sensation while following the clinician's oscillating hand to facilitate bilateral eye movements. This phase of identifying and processing sensations that emerged with IE was considered completed when the participant was able to re-imagine the entire traumatic experience with an acceptable (low) level of physiological reaction to the original distressing scene. In the IR phase, participants were instructed to visualize and imagine a new way to change or substitute the original negative traumatic experience with positive imagery, while also performing bilateral eye movements, as directed by the therapist. This technique of imaging new material to be added to or overwrite the original traumatic material is consistent with the process of memory reconsolidation (Lee, Nader, \& Schiller, 2017). The IR phase was considered complete when the participant reported "seeing" (imagining) the memory in the new, preferred manner, as opposed to the original traumatic imagery. Additional information on the ART protocol has been previously published (Kip et al., 2012; Kip et al., 2014; Kip et al., 2013).

\section{Statistical Methods}

Demographic and clinical characteristics of study participants by prior history of PTSD treatment status were compared using Fisher's exact test for categorical variables and Student's $t$-tests for continuous variables. Comparisons were made among the subjects who received and completed treatment with ART. Treatment outcomes were assessed based on mean score changes (pre-to-post ART treatment) on the PCL-M, CES-D, STICSA, BSI, and PSQI instruments, as well as by calculation of Cohen's $d$ effect size and corresponding 95\% confidence intervals (Morris \& DeShon, 2002). To examine potential differences in ART treatment response among groups for the first classification of prior PTSD treatment, analysis of covariance (ANCOVA) models were fit, including adjustment for baseline value of the evaluated outcome, PCL-M, PSQI, disability, antidepressant, antianxiety, and sleep medication. Moreover, 
medRxiv preprint doi: https://doi.org/10.1101/2021.04.15.21255572; this version posted April 17, 2021. The copyright holder for this preprint (which was not certified by peer review) is the author/funder, who has granted medRxiv a license to display the preprint in perpetuity.

All rights reserved. No reuse allowed without permission.

the proportion of subjects who experienced a clinically and statistically meaningful reduction in symptoms of PTSD was defined using the established metric of $\geq 10$-point reduction on the PCLM (PTSD checklist) and compared by prior treatment history group by chi-square analysis. For the second classification of prior PTSD treatment, ANCOVA was again used with statistical adjustment for baseline value of the evaluated outcome, PCL-M, BSI, CES-D, disability, antidepressant, antianxiety, and medication use for sleep and pain. Statistical significance was set at a $p<.05$.

\section{Results}

\section{Types of Prior History of PTSD Treatment (Classification \#1)}

\section{Demographic Characteristics}

Among 148 participants who enrolled and started treatment with ART, 106 (71.6\%) completed treatment in a mean of 3.5 treatment sessions (Table 1). Of those who completed ART, 55 participants (51.9\%) provided a 6-month follow-up data. The mean age of the study participants was 43.8 years, with $94.6 \%$ identifying as male, and $84.3 \%$ identifying as White. The study population was predominantly veterans (87.1\%) with prior Army service (57.4\%) and who had experienced high combat-related activity $(81.8 \%)$, and $71.6 \%$ witnessed death or execution. Over half had trauma-related symptoms for 11 or more years $(53.8 \%)$. Of note, $53.6 \%$ of participants in the first-line psychotherapy group were more likely on disability for PTSD or other mental health disorders, compared to the treatment-naïve group (15.6\%), a statistically significant difference $(p=0.01)$.

\section{Clinical Presentation and Treatment Results}

Study participants in the treatment-refractory groups (medication only, other psychotherapy, and first-line psychotherapy) had significantly higher mean baseline values on 
medRxiv preprint doi: https://doi.org/10.1101/2021.04.15.21255572; this version posted April 17, 2021. The copyright holder for this preprint (which was not certified by peer review) is the author/funder, who has granted medRxiv a license to display the preprint in perpetuity.

All rights reserved. No reuse allowed without permission.

the PCL-M for PTSD and PSQI for sleep quality compared to the treatment-naïve group ( $p=$ 0.01, Table 1). The first-line psychotherapy (88.0\%) and the treatment-naïve group (87.5\%) had the highest $\geq 10$-point reduction on the PCL-M post-treatment and at follow-up, respectively (Figure 1). As seen at the top of Table 2, all groups experienced significant pre-to-post withingroup changes in PTSD symptoms: 15.4-point reduction in the medication group (effect size $=$ 1.11), 24.1 points in the first-line psychotherapy group (effect size $=1.88), 19.2$ points in the other psychotherapy group (effect size $=1.03$ ), and 25.1 points in the treatment-naïve group (effect size $=1.48$ ). Thus, participants with a prior history of first-line psychotherapy experienced substantial clinical benefit with ART, as did the treatment naïve group $(p=0.02$ for between-group comparison). In assessing treatment-related changes in PTSD-related comorbidities, all groups showed similar modest-to-large improvements for symptoms of psychological distress, depression, anxiety, and sleep quality. At a 6-month follow-up, the largest sustained reductions in symptoms of PTSD occurred in the treatment naïve group ( -28.3 points, effect size $=1.48)$ and the first-line psychotherapy group $(-28.9$ points, effect size $=1.53$; Table 2, bottom).

\section{Prior History of PTSD Treatment (Classification \#2)}

\section{Demographic Characteristics}

Using the second definition of prior history of PTSD treatment, a total of 198 eligible military service members/veterans started treatment with ART, and 153 (77.3\%) completed treatment in a mean of 3.5 treatment sessions (Table 3). Of the 153 subjects who completed treatment, $93(60.8 \%)$ also provided 3- or 6-month follow-up data. The mean age of study subjects was $43.4 \pm 13.2$ years, with $91.4 \%$ identifying as male, $84.2 \%$ identifying as White. Over half of the participants $(52.8 \%)$ had trauma-related symptoms for more than 11 years. The 
medRxiv preprint doi: https://doi.org/10.1101/2021.04.15.21255572; this version posted April 17, 2021. The copyright holder for this preprint (which was not certified by peer review) is the author/funder, who has granted medRxiv a license to display the preprint in perpetuity.

All rights reserved. No reuse allowed without permission.

majority of the study population were veterans (83.3\%) with prior Army service $(57.6 \%)$, had combat-related activity (84.4\%), witnessed death or execution (72.1\%), and had five or more traumas or major injuries (52.9\%). Over half (53.3\%) of study participants previously treated with medication and psychotherapy for PTSD were on disability for PTSD or other mental health disorders, compared to just $14.3 \%$ in the treatment-naïve group $(p<.01)$.

\section{Clinical Presentation and Treatment Results}

The treatment-refractory groups (medication only, psychotherapy only, and psychotherapy and medication) had higher baseline scores on the PCL-M for PTSD, BSI for psychological distress, and CES-D for depression compared to the treatment-naïve group (Table 3). The treatment-naïve group had the highest $\geq 10$-point reduction on the PCL-M (post-treatment $82.4 \%$, follow-up $87 \%$ ), using the definition of statistical and clinically meaningful change (Figure 1). All treatment groups that completed treatment with ART experienced substantial preto-post reductions in PTSD symptoms (PCL-M): 16.5-point reduction in the medication-only group $($ effect size $=1.20), 15.5$ points in the psychotherapy group $($ effect size $=0.86), 20.2$ points in the medication and psychotherapy group (effect size $=1.31$, and 20.6 points in the treatment-naïve group (effect size $=1.39$; Table 4, top). The mean score reduction on the PCL-M was not statistically different between the four groups after adjusting for baseline value and other confounders $(p=0.19)$, indicating ART was approximately equally effective among all treatment-refractory groups and those with no prior treatment history. Similar reductions of comorbidities were observed in all groups after completing treatment with ART, including symptom measures of psychological distress, depression, anxiety, and sleep quality. The reductions in PTSD and its related symptoms generally persisted at 3- or 6- months follow-up (Table 4, bottom). 
medRxiv preprint doi: https://doi.org/10.1101/2021.04.15.21255572; this version posted April 17, 2021. The copyright holder for this preprint (which was not certified by peer review) is the author/funder, who has granted medRxiv a license to display the preprint in perpetuity.

\section{Discussion}

Post-traumatic stress disorder is a debilitating psychiatric disorder, particularly among U.S. military service members and veterans. First-line treatments including Cognitive Processing Therapy (CPT) and Prolonged Exposure (PE) therapy, while moderately successful in randomized controlled trials within the civilian population, produce less-than-optimal outcomes for military-related PTSD (Steenkamp et al., 2020). Poor treatment retention, emotionally taxing interventions, and nonresponse rates point to a need for more efficacious psychotherapies for PTSD among servicemen and women (Najavits, 2015; Steenkamp et al., 2020).

This study examined immediate, short-term (three months), and long-term (six months) reductions in PTSD and related mental health symptoms for U.S. military service/veteran participants following completion of a new, innovative trauma-focused treatment modality Accelerated Resolution Therapy (ART). The majority of participants had sought prior treatment, including psychotropic medications and first-line psychotherapies as recommended by guidelines from the VA/DoD (The Management of Posttraumatic Stress Disorder Work Group, 2017). Overall, ART was proven to be an effective psychotherapy in reducing post-traumatic stress symptoms and ancillary symptoms of psychological distress, depression, anxiety, and sleep quality after an average of only 3.5 ART sessions. Specifically, ART was shown to be equally effective at significantly reducing PTSD symptoms among groups with treatment-refractory PTSD or individuals with no prior PTSD treatment history. The treatment completion rate ranged from $70 \%$ to $80 \%$, which appears to be higher than most first-line trauma-focused therapies (Foa et al., 2018; Najavits, 2015; Nidich et al., 2018; Rauch et al., 2019; Resick et al., 2017; Resick et al., 2015; Steenkamp et al., 2015; Steenkamp et al., 2020). Moreover, participants' large symptom reductions persevered up to six months after ART, especially for individuals who had 
medRxiv preprint doi: https://doi.org/10.1101/2021.04.15.21255572; this version posted April 17, 2021. The copyright holder for this preprint (which was not certified by peer review) is the author/funder, who has granted medRxiv a license to display the preprint in perpetuity.

All rights reserved. No reuse allowed without permission.

either never sought PTSD treatment in the past or had previously received a first-line psychotherapy treatment. In contrast, prior studies have shown that PTSD symptoms tend to persist among service members and veterans, particularly those with high combat experience and comorbid concerns like depression (Armenta et al., 2018). While not a direct randomized comparison, the present findings suggest that ART was equally if not more effective than most recommended treatments for PTSD among military service members and veterans, even those who have had combat experiences and comorbid mental health symptoms of depression and anxiety. The findings also suggest that ART may be more effective than medication, psychotherapy, or a combination of medication and psychotherapy for individuals who had never sought treatment before, even with high combat and comorbid depression.

Previous studies have attempted to isolate factors that contributed to treatment dropout, poor response rates, low help-seeking, and risks for persistent PTSD symptoms, with varying results (Armenta et al., 2018; Najavits, 2015; Xue et al., 2015). And while the reasons for unsuccessful prior treatment or lack of treatment-seeking in the past is not known about the current study's sample population, common factors that have been identified in previous studies are combat experiences, PTSD symptom severity, poor sleep quality, and comorbid depression, anxiety, and other mental health disorders that can complicate treatment outcomes. The findings in the present study demonstrated that not only did participants' PTSD symptoms improve significantly in a brief treatment period, so did their depression, sleep quality, anxiety, and overall psychological distress after completing ART. This suggests that ART may be particularly helpful for more severe and complex symptom constellations for U.S. military members and veterans.

\section{Limitations and Future Directions}


medRxiv preprint doi: https://doi.org/10.1101/2021.04.15.21255572; this version posted April 17, 2021. The copyright holder for this preprint (which was not certified by peer review) is the author/funder, who has granted medRxiv a license to display the preprint in perpetuity.

All rights reserved. No reuse allowed without permission.

The results of this study are a promising step toward identifying brief, affordable, less emotionally demanding, and successful treatment for persistent and treatment-refractory PTSD among U.S. military members and veterans; however, there are a few limitations. While the completion rate for ART was higher compared to most first-line trauma-focused psychotherapies, some participants did not complete treatment and did not complete the followup assessments. Some hypotheses are that symptoms remitted, and the client did not wish to return, or perhaps they were no longer clients of the VA at the time of follow-up. However, those who completed the treatment and provide follow-up data appeared to have higher rates of symptom reduction at follow-up than other first-line psychotherapies (Foa et al., 2018; Nidich et al., 2018; Rauch et al., 2019; Resick et al., 2017; Resick et al., 2015; Steenkamp et al., 2020). The present study's sample population was representative of VA clients; however, these specific results cannot be generalized to other populations suffering from PTSD. Future research should be conducted on U.S. military service members and veterans in non-VA outpatient settings to compare these findings, as well as non-military civilian populations using the same assessments and follow-up timelines.

\section{Conclusions}

Accelerated Resolution Therapy (ART) continues to show evidence as an effective treatment modality for PTSD (Kip et al., 2012; Kip et al., 2013; Kip et al., 2016) and related mental health concerns like depression (Kip et al., 2013), bereavement (Buck et al., 2020), and even pain (Kip et al., 2014). ART meets the VA/DoD Clinical Practice Guidelines (Department of Defense, 2017) criteria for first-line psychotherapies for the treatment of PTSD, as it is an individualized, manualized, trauma-focused psychotherapy (Kip \& Diamond, 2018) and contains the most critical components of evidence-based trauma-focused treatment (Waits et al., 2017). 
medRxiv preprint doi: https://doi.org/10.1101/2021.04.15.21255572; this version posted April 17, 2021. The copyright holder for this preprint (which was not certified by peer review) is the author/funder, who has granted medRxiv a license to display the preprint in perpetuity.

All rights reserved. No reuse allowed without permission.

Based on our results, not only should ART be considered as a first-line treatment for PTSD, but also this modality is to be given first consideration for military service members and veterans who are at high risk of treatment dropout and/or have treatment-refractory PTSD accompanied by other mental health symptoms. Similarly, ART should also be considered when minimal or no reductions in PTSD and related symptoms are observed following the initiation of PE, CPT, or similar treatments.

\section{Acknowledgments}

We thank the U.S. service members and veterans who participated in this research.

\section{Disclosure statement}

No potential conflict of interest was reported by the authors.

\section{Data availability statement}

Inquires related to the data that support the findings should be directed to the corresponding author. The data are not publicly available due to privacy and confidentiality requirements of the Institutional Review Board (IRB) at the University of South Florida (USF), the parent institution for the study. Requests for data access, if approved through the corresponding author and USF IRB, require a Data Authorization and Data Sharing Agreement between USF and the requesting institution.

\section{Funding}

This work was supported by the U.S. Army Medical Research and Materiel Command, and Telemedicine and Advanced Technology Research Center under Contract W81XWH-10-10719, and by funding support from the Chris T. Sullivan Foundation.

\section{Ethics statement}


medRxiv preprint doi: https://doi.org/10.1101/2021.04.15.21255572; this version posted April 17, 2021. The copyright holder for this preprint (which was not certified by peer review) is the author/funder, who has granted medRxiv a license to display the preprint in perpetuity. All rights reserved. No reuse allowed without permission.

Ethical approval for this study was obtained by Institutional Review Board at University of South Florida (USF). All participants provided written informed consent. 
medRxiv preprint doi: https://doi.org/10.1101/2021.04.15.21255572; this version posted April 17, 2021. The copyright holder for this preprint

(which was not certified by peer review) is the author/funder, who has granted medRxiv a license to display the preprint in perpetuity.

All rights reserved. No reuse allowed without permission.

\section{References}

American Psychiatric Association. (2013). Diagnostic and statistical manual of mental disorders (5th ed.). Washington, DC: American Psychiatric Publishing.

American Psychiatric Association. (2020). Help With Posttraumatic Stress Disorder (PTSD). https://www.psychiatry.org/patients-families/ptsd

American Psychological Association Guideline Development Panel for the Treatment of PTSD in Adults. (2017). Clinical practice guideline for the treatment of posttraumatic stress disorder (PTSD) in adults. https://www.apa.org/ptsd-guideline/ptsd.pdf

Armenta, R. F., Rush, T., LeardMann, C. A., Millegan, J., Cooper, A., \& Hoge, C. W. (2018). Factors associated with persistent posttraumatic stress disorder among U.S. military service members and veterans. BMC Psychiatry, 18(1), 48. doi:10.1186/s12888-018$1590-5$

Blanchard, E. B., Jones-Alexander, J., Buckley, T. C., \& Forneris, C. A. (1996). Psychometric properties of the PTSD checklist (PCL). Behaviour Research and Therapy, 34(8), 669673. https://doi.org/10.1016/0005-7967(96)00033-2

Bryan, A. O., Theriault, J. L., \& Bryan, C. J. (2015). Self-forgiveness, posttraumatic stress, and suicide attempts among military personnel and veterans. Traumatology, 21(1), 40-46. https://doi.org/10.1037/trm0000017

Buysse, D. J., Reynolds, C. F., Monk, T. H., Berman, S. R., \& Kupfer, D. J. (1989). The Pittsburgh sleep quality index: A new instrument for psychiatric practice and research. Psychiatry Research, 28(2), 193-213. https://doi.org/10.1016/0165-1781(89)90047-4 
medRxiv preprint doi: https://doi.org/10.1101/2021.04.15.21255572; this version posted April 17, 2021. The copyright holder for this preprint (which was not certified by peer review) is the author/funder, who has granted medRxiv a license to display the preprint in perpetuity.

All rights reserved. No reuse allowed without permission.

Centers for Disease Control and Prevention. (2020). Preventing Adverse Childhood Experiences. https://www.cdc.gov/violenceprevention/aces/fastfact.html?CDC_AA_refVal=https\%3A \%2F\%2Fwww.cdc.gov $\% 2$ Fviolenceprevention $\% 2$ Facestudy $\% 2$ Ffastfact.html

Cusack, K., Jonas, D. E., Forneris, C. A., Wines, C., Sonis, J., Middleton, J. C., . . Gaynes, B. N. (2016). Psychological treatments for adults with posttraumatic stress disorder: A systematic review and meta-analysis. Clinical Psychology Review, 43, 128-141. https://doi.org/10.1016/j.cpr.2015.10.003

Department of Defense. (2017). Population Representation in the Military Services: Fiscal Year 2017 Summary Report. https://prhome.defense.gov/Portals/52/Documents/MRA_Docs/MPP/AP/poprep/2017/Ex ecutive $\% 20$ Summary.pdf

Foa, E. B., McLean, C. P., Zang, Y., Rosenfield, D., Yadin, E., Yarvis, J. S., . . Peterson, A. L. (2018). Effect of Prolonged Exposure Therapy Delivered Over 2 Weeks vs 8 Weeks vs Present-Centered Therapy on PTSD Symptom Severity in Military Personnel: A Randomized Clinical Trial. JAMA, 319(4), 354-364. https://doi.org/10.1001/jama.2017.21242

Gates, M. A., Holowka, D. W., Vasterling, J. J., Keane, T. M., Marx, B. P., \& Rosen, R. C. (2012). Posttraumatic Stress Disorder in Veterans and Military Personnel: Epidemiology, Screening, and Case Recognition(4), 361. https://doi.org/10.1037/a0027649

Grös, D. F., Antony, M. M., Simms, L. J., \& McCabe, R. E. (2007). Psychometric properties of the State-Trait Inventory for Cognitive and Somatic Anxiety (STICSA): comparison to the State-Trait Anxiety Inventory (STAI). Psychological Assessment, 19(4), 369-381. https://doi.org/10.1037/1040-3590.19.4.369 
medRxiv preprint doi: https://doi.org/10.1101/2021.04.15.21255572; this version posted April 17, 2021. The copyright holder for this preprint (which was not certified by peer review) is the author/funder, who has granted medRxiv a license to display the preprint in perpetuity. All rights reserved. No reuse allowed without permission.

Hamblen, J. L., Norman, S. B., Sonis, J. H., Phelps, A. J., Bisson, J. I., Nunes, V. D., . . . Schnurr, P. P. (2019). A Guide to Guidelines for the Treatment of Posttraumatic Stress Disorder in Adults: An Update(3), 359. http://dx.doi.org/10.1037/pst0000231

Kip, K. E., Berumen, J., Zeidan, A. R., Hernandez, D. F., \& Finnegan, A. P. (2019). The emergence of accelerated resolution therapy for treatment of post-traumatic stress disorder: A review and new subgroup analyses. Counselling and Psychotherapy Research, 19(2), 117-129. https://doi.org/10.1002/capr.12210

Kip, K. E., D'Aoust, R. F., Hernandez, D. F., Girling, S. A., Cuttino, B., Long, M. K., . . . Rosenzweig, L. (2016). Evaluation of brief treatment of symptoms of psychological trauma among veterans residing in a homeless shelter by use of Accelerated Resolution Therapy. Nursing Outlook, 64(5), 411-423. https://doi.org/10.1016/j.outlook.2016.04.006

Kip, K. E., \& Diamond, D. M. (2018). Clinical, Empirical, and Theoretical Rationale for Selection of Accelerated Resolution Therapy for Treatment of Post-traumatic Stress Disorder in VA and DoD Facilities. Military Medicine, 183(9-10), 314-321. https://doi.org/10.1093/milmed/usy027

Kip, K., Elk, C., Sullivan, K., Kadel, R., Lengacher, C., Long, C., Rosenzweig, L., Shuman, A., Hernandez, D., Street, J., Girling, S., \& Diamond, D. (2012). Brief Treatment of Symptoms of Post-Traumatic Stress Disorder (PTSD) by Use of Accelerated Resolution Therapy (ART®) . Behavioral Sciences, 2(2), 115-134.

https://doi.org/10.3390/bs2020115

Kip, K. E., Hernandez, D. F., Shuman, A., Witt, A., Diamond, D. M., Davis, S., . . Rosenzweig, L. (2015). Comparison of Accelerated Resolution Therapy (ART) for Treatment of 
medRxiv preprint doi: https://doi.org/10.1101/2021.04.15.21255572; this version posted April 17, 2021. The copyright holder for this preprint (which was not certified by peer review) is the author/funder, who has granted medRxiv a license to display the preprint in perpetuity. All rights reserved. No reuse allowed without permission.

Symptoms of PTSD and Sexual Trauma Between Civilian and Military Adults. Military Medicine, 180(9), 964-971. https://doi.org/10.7205/milmed-d-14-00307

Kip, K. E., Rosenzweig, L., Hernandez, D. F., Shuman, A., Sullivan, K. L., Long, C. J., . . . Diamond, D. M. (2013). Randomized controlled trial of accelerated resolution therapy (ART) for symptoms of combat-related post-traumatic stress disorder (PTSD). Military Medicine, 178(12), 1298-1309. https://doi.org/10.7205/milmed-d-13-00298

Kip, K. E., Shuman, A., Hernandez, D. F., Diamond, D. M., \& Rosenzweig, L. (2014). Case report and theoretical description of accelerated resolution therapy (ART) for militaryrelated post-traumatic stress disorder. Military Medicine, 179(1), 31-37. https://doi.org/10.7205/milmed-d-13-00229

Kip, K., Sullivan, K., Lengacher, C., Rosenzweig, L., Hernandez, D., Kadel, R., Kozel, F., Shuman, A., Girling, S., Hardwick, M., \& Diamond, D. (2013). Brief treatment of cooccurring post-traumatic stress and depressive symptoms by use of accelerated resolution therapy. Front Psychiatry, 4, 11. https://doi.org/10.3389/fpsyt.2013.00011

Kok, B. C., Herrell, R. K., Thomas, J. L., \& Hoge, C. W. (2012). Posttraumatic stress disorder associated with combat service in Iraq or Afghanistan: reconciling prevalence differences between studies. Journal of Nervous and Mental Disease, 200(5), 444-450. https://doi.org/10.1097/nmd.0b013e3182532312

Lee, J. L. C., Nader, K., \& Schiller, D. (2017). An Update on Memory Reconsolidation Updating. Trends in Cognitive Sciences, 21(7), 531-545. https://doi.org/10.1016/j.tics.2017.04.006

Levine, A. B., Levine, L. M., \& Levine, T. B. (2014). Posttraumatic stress disorder and cardiometabolic disease. Cardiology, 127(1), 1-19. https://doi.org/10.1159/000354910 
medRxiv preprint doi: https://doi.org/10.1101/2021.04.15.21255572; this version posted April 17, 2021. The copyright holder for this preprint (which was not certified by peer review) is the author/funder, who has granted medRxiv a license to display the preprint in perpetuity. All rights reserved. No reuse allowed without permission.

Marmar, C., Schlenger, W., Henn-Haase, C., Qian, M., Purchia, E., Li, M., Corry, N., Williams, C., Ho, C., Horesh, D., Karstoft, K., Shalev, A., \& Kulka, R. (2015). Course of Posttraumatic Stress Disorder 40 Years After the Vietnam War: Findings From the National Vietnam Veterans Longitudinal Study. JAMA Psychiatry, 72(9), 875-881. https://doi.org/10.1001/jamapsychiatry.2015.0803

Meachen, S.-J., Hanks, R. A., Millis, S. R., \& Rapport, L. J. (2008). The Reliability and Validity of the Brief Symptom Inventory- 18 in Persons With Traumatic Brain Injury. Archives of Physical Medicine and Rehabilitation, 89(5), 958-965. https://doi.org/10.1016/j.apmr.2007.12.028

Morris, S. B., \& DeShon, R. P. (2002). Combining effect size estimates in meta-analysis with repeated measures and independent-groups designs. Psychological Methods, 7(1), 105125. https://doi.org/10.1037/1082-989x.7.1.105

Najavits, L. M. (2015). The problem of dropout from "gold standard" PTSD therapies. F1000Prime Rep, 7, 43. https://doi.org/10.12703/p7-43

National Center for PTSD. (2019). Understanding PTSD and PTSD Treatment. https://www.ptsd.va.gov/publications/print/understandingptsd_booklet.pdf

National Collaborating Centre for Mental Health (UK). (2005). Post-Traumatic Stress Disorder: The Management of PTSD in Adults and Children in Primary and Secondary Care. Leicester (UK): Gaskell.

National Institude of Mental Health. (2019). Post-Traumatic Stress Disorder. https://www.nimh.nih.gov/health/topics/post-traumatic-stress-disorder-ptsd/index.shtml Nidich, S., Mills, P. J., Rainforth, M., Heppner, P., Schneider, R. H., Rosenthal, N. E., Salerno, J., Gaylord-King, C., \& Rutledge, T. (2018). Non-trauma-focused meditation versus 
medRxiv preprint doi: https://doi.org/10.1101/2021.04.15.21255572; this version posted April 17, 2021. The copyright holder for this preprint (which was not certified by peer review) is the author/funder, who has granted medRxiv a license to display the preprint in perpetuity. All rights reserved. No reuse allowed without permission.

exposure therapy in veterans with post-traumatic stress disorder: a randomised controlled trial. The Lancet Psychiatry, 5(12), 975-986. https://doi.org/10.1016/s22150366(18)30384-5

Pietrzak, R. H., Goldstein, R. B., Southwick, S. M., \& Grant, B. F. (2011). Prevalence and Axis I comorbidity of full and partial posttraumatic stress disorder in the United States: results from Wave 2 of the National Epidemiologic Survey on Alcohol and Related Conditions. Journal of Anxiety Disorders, 25(3), 456-465.

https://doi.org/10.1016/j.janxdis.2010.11.010

Radloff, L. S. (1977). The CES-D Scale: A Self-Report Depression Scale for Research in the General Population. Applied Psychological Measurement, 1(3), 385-401. https://doi.org/10.1177/014662167700100306

Ramchand, R., Schell, T. L., Karney, B. R., Osilla, K. C., Burns, R. M., \& Caldarone, L. B. (2010). Disparate prevalence estimates of PTSD among service members who served in Iraq and Afghanistan: possible explanations. Journal of Traumatic Stress, 23(1), 59-68. https://doi.org/10.1002/jts.20486

Rauch, S. A. M., Kim, H. M., Powell, C., Tuerk, P. W., Simon, N. M., Acierno, R., .. . Hoge, C. W. (2019). Efficacy of Prolonged Exposure Therapy, Sertraline Hydrochloride, and Their Combination Among Combat Veterans With Posttraumatic Stress Disorder: A Randomized Clinical Trial. JAMA Psychiatry, 76(2), 117-126. https://doi.org/10.1001/jamapsychiatry.2018.3412

Resick, P., Wachen, J., Dondanville, K., Pruiksma, K., Yarvis, J., Peterson, A., Mintz, J., Borah, E., Brundige, A., Hembree, E., Litz, B., Roache, J., \& Young-McCaughan, S. (2017). Effect of Group vs Individual Cognitive Processing Therapy in Active-Duty Military 
medRxiv preprint doi: https://doi.org/10.1101/2021.04.15.21255572; this version posted April 17, 2021. The copyright holder for this preprint (which was not certified by peer review) is the author/funder, who has granted medRxiv a license to display the preprint in perpetuity.

All rights reserved. No reuse allowed without permission.

Seeking Treatment for Posttraumatic Stress Disorder: A Randomized Clinical Trial. JAMA Psychiatry, 74(1), 28-36. https://doi.org/10.1001/jamapsychiatry.2016.2729

Resick, P., Wachen, J., Mintz, J., Young-McCaughan, S., Roache, J., Borah, A., Borah, E., Dondanville, K., Hembree, E., Litz, B., \& Peterson, A. (2015). A randomized clinical trial of group cognitive processing therapy compared with group present-centered therapy for PTSD among active duty military personnel. Journal of Consulting and Clinical Psychology, 83(6), 1058-1068. https://doi.org/10.1037/ccp0000016

Steenkamp, M. M., Litz, B. T., Hoge, C. W., \& Marmar, C. R. (2015). Psychotherapy for Military-Related PTSD: A Review of Randomized Clinical Trials. JAMA, 314(5), 489500. https://doi.org/10.1001/jama.2015.8370

Steenkamp, M. M., Litz, B. T., \& Marmar, C. R. (2020). First-line Psychotherapies for MilitaryRelated PTSD. JAMA, 323(7), 656-657. https://doi.org/10.1001/jama.2019.20825

The Management of Posttraumatic Stress Disorder Work Group. (2017). VA/DoD Clinical Practice Guideline for the Management of Post-Traumatic Stress and Acute Stress Disorder. Department of Veterans Affairs and Department of Defense. https://www.healthquality.va.gov/guidelines/MH/ptsd/VADoDPTSDCPGFinal082917.pd $\underline{\mathrm{f}}$

U.S. Department of Veterans Affairs. (2019). PTSD: National Center for PTSD. https://www.ptsd.va.gov/understand/common/common_adults.asp

U.S. Department of Veterans Affairs. (2021). PTSD: National Center for PTSD. https://www.ptsd.va.gov/index.asp

United States Census Bureau. (2019). Veteran status: 2019 American Communiry Survey 1-year estimates. 
medRxiv preprint doi: https://doi.org/10.1101/2021.04.15.21255572; this version posted April 17, 2021. The copyright holder for this preprint (which was not certified by peer review) is the author/funder, who has granted medRxiv a license to display the preprint in perpetuity.

All rights reserved. No reuse allowed without permission.

\section{https://data.census.gov/cedsci/table?q=Owner\%20Veterans\%20Status\&t=Veterans\&tid=}

\section{ACSST1Y2019.S2101\&hidePreview=false}

Waits, W., Marumoto, M., \& Weaver, J. (2017). Accelerated Resolution Therapy (ART): a

Review and Research to Date. Curr Psychiatry Rep, 19(3), 18.

https://doi.org/10.1007/s11920-017-0765-y

Watts, B. V., Schnurr, P. P., Mayo, L., Young-Xu, Y., Weeks, W. B., \& Friedman, M. J. (2013).

Meta-analysis of the efficacy of treatments for posttraumatic stress disorder. Journal of

Clinical Psychiatry, 74(6), e541-550. https://doi.org/10.4088/jcp.12r08225

Weathers, F., Litz, T. B., Herman, S. D., Huska, A. J., \& Keane, M. T. (1993). The PTSD

Checklist (PCL): Reliability, Validity, and Diagnostic Utility [Paper presentation].

Annual Convention of the International Society for Traumatic Stress Studies, San Antonio, TX.

Wisco, B. E., Marx, B. P., Wolf, E. J., Miller, M. W., Southwick, S. M., \& Pietrzak, R. H.

(2014). Posttraumatic stress disorder in the US veteran population: results from the National Health and Resilience in Veterans Study. Journal of Clinical Psychiatry, 75(12), 1338-1346. https://doi.org/10.4088/jcp.14m09328

Xue, C., Ge, Y., Tang, B., Liu, Y., Kang, P., Wang, M., \& Zhang, L. (2015). A meta-analysis of risk factors for combat-related PTSD among military personnel and veterans. PloS One, 10(3), e0120270-e0120270. https://doi.org/10.1371/journal.pone.0120270 


\section{Pre and post treatment}

\section{Treatment Response Rates on PCL-M Score}

\section{Response \\ Rate (\%)}

100

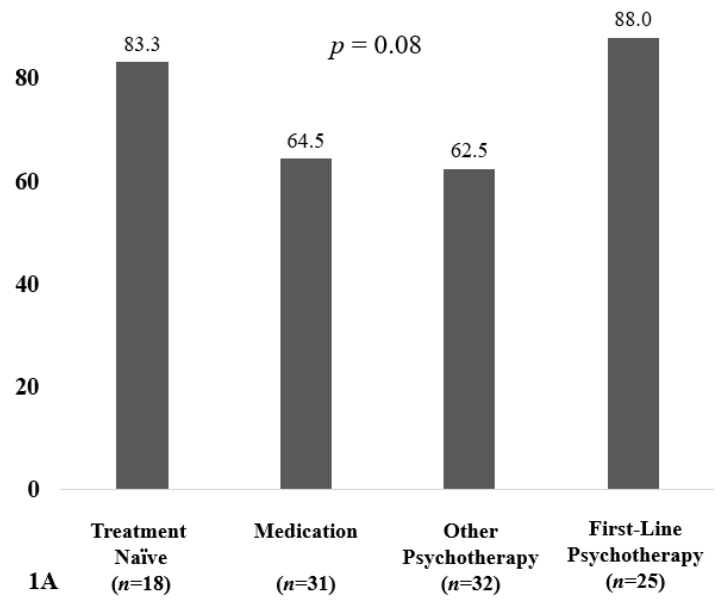

\section{Response}

Rate (\%)

100

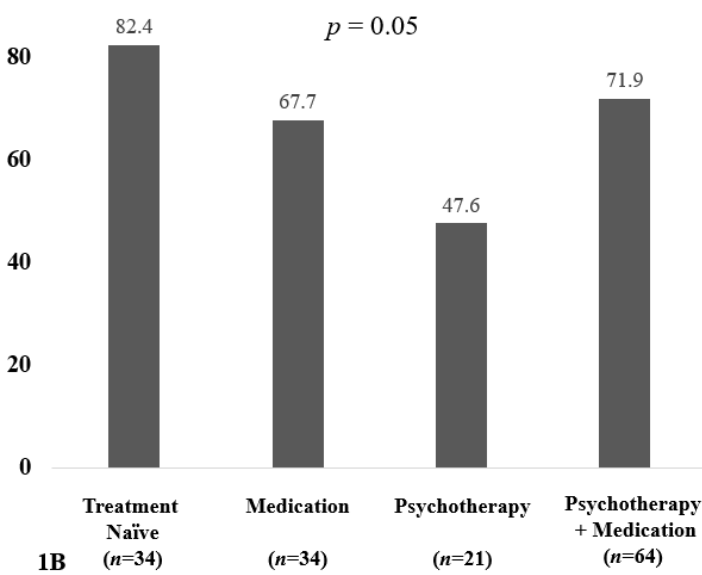

Treatment Classification \#1

Treatment Classification \#2

Pre and follow-up treatment

\section{Response}

Rate (\%)

100

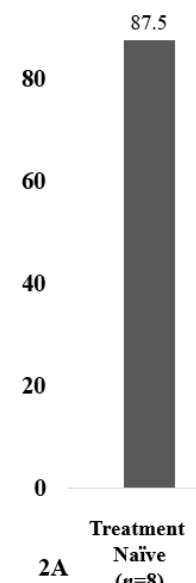

$p=0.04$

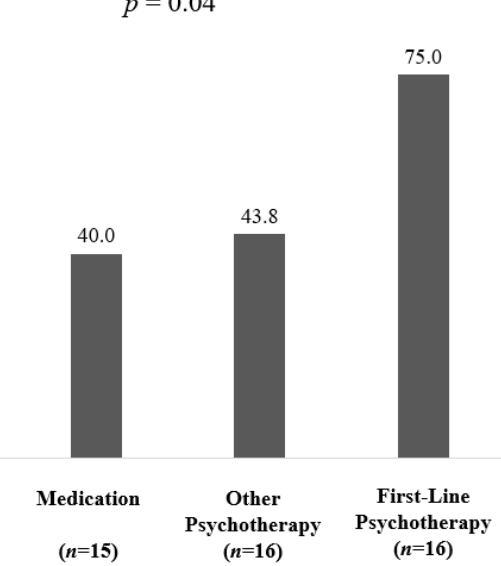

Treatment Classification \#1

Response

Rate (\%)

100

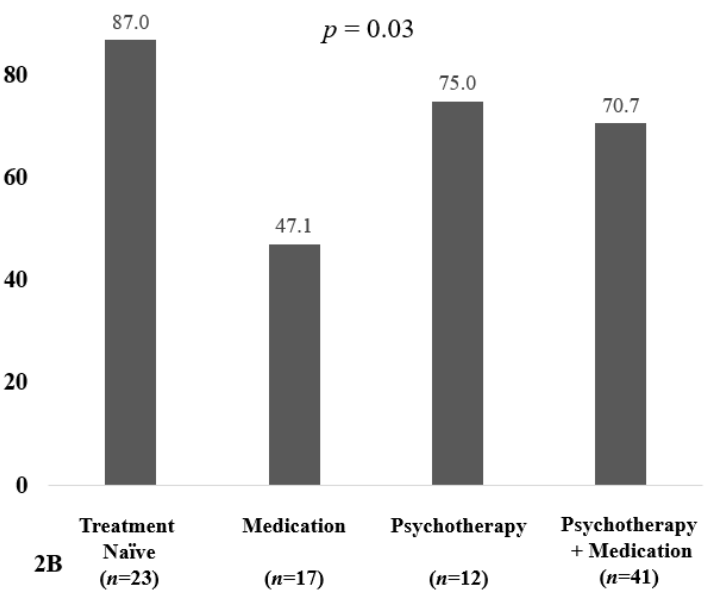

Treatment Classification \#2

Figure 1. Histogram of treatment response rates defined as $\geq 10$-point reduction in PTSD symptoms on the 17-item PCL-M (PTSD) checklist by classification of prior history of PTSD treatment. The top two figures (1A and 1B) present response rates among subjects pre and post treatment with ART. The bottom two figures (2A and $2 \mathrm{~B}$ ) present response rates among subjects pre and follow-up treatment with ART. ART: Accelerated Resolution Therapy; PTSD: post-traumatic stress disorder; PCL-M: PTSD Checklist. Classification \#1 is types of prior history of PTSD treatment. Classification \#2 is prior history of PTSD treatment 
Table 1. Demographic and Clinical Characteristics of Study Participants by Types of Prior History of PTSD Treatment (Classification \#1)

\begin{tabular}{|c|c|c|c|c|c|c|}
\hline \multirow[b]{2}{*}{ Characteristics } & \multirow[b]{2}{*}{$\begin{array}{c}\text { All } \\
(\mathrm{n}=148)\end{array}$} & \multicolumn{4}{|c|}{ Types of Prior History of PTSD Treatment } & \multirow[b]{2}{*}{$p$-Value } \\
\hline & & $\begin{array}{c}\text { Treatment- } \\
\text { naïve }(\mathrm{n}=33)\end{array}$ & $\begin{array}{l}\text { Medication } \\
(\mathrm{n}=40)\end{array}$ & $\begin{array}{c}\text { Other } \\
\text { Psychotherapy } \\
(\mathrm{n}=42)\end{array}$ & $\begin{array}{c}\text { First-line } \\
\text { Psychotherapy } \\
(\mathrm{n}=33)\end{array}$ & \\
\hline Age in years, mean $\pm S D$ & $43.8 \pm 13.4$ & $45.7 \pm 15.2$ & $45.6 \pm 13.1$ & $41.7 \pm 12.8$ & $42.5 \pm 12.3$ & 0.43 \\
\hline Male gender, $\%$ & 94.6 & 93.9 & 90.0 & 100.0 & 93.9 & 0.25 \\
\hline Race, $\%$ & & & & & & 0.99 \\
\hline Other & 2.7 & 3.0 & 2.6 & 2.4 & 3.1 & \\
\hline Years of education, mean \pm SD & $14.4 \pm 2.7$ & $14.2 \pm 3.2$ & $14.4 \pm 3.0$ & $14.2 \pm 2.0$ & $14.9 \pm 2.5$ & 0.70 \\
\hline Current military status, $\%$ & & & & & & 0.64 \\
\hline Active duty & 6.8 & 9.4 & 10.0 & 7.1 & 0.0 & \\
\hline Reservist & 6.1 & 9.4 & 5.0 & 4.8 & 6.1 & \\
\hline Discharged/veteran & 87.1 & 81.3 & 85.0 & 88.1 & 93.9 & \\
\hline Navy & 12.8 & 24.2 & 10.0 & 7.1 & 12.1 & \\
\hline Marine Corps & 13.5 & 12.1 & 15.0 & 4.8 & 24.2 & \\
\hline Air force & 9.5 & 12.1 & 7.5 & 14.3 & 3.0 & \\
\hline National guard & 6.8 & 9.1 & 5.0 & 9.5 & 3.0 & \\
\hline \multicolumn{7}{|l|}{ Clinical characteristics } \\
\hline PCL-M (PTSD checklist), mean \pm SD & $58.5 \pm 13.8$ & $52.3 \pm 15.5$ & $58.8 \pm 12.2$ & $58.4 \pm 14.8$ & $64.6 \pm 9.9$ & $0.01 *$ \\
\hline Brief Symptom Inventory, mean $\pm \mathrm{SD}$ & $28.4 \pm 13.7$ & $24.5 \pm 15.3$ & $28.6 \pm 12.4$ & $27.1 \pm 13.6$ & $32.3 \pm 14.1$ & 0.18 \\
\hline CES-D (depression), mean \pm SD & $27.6 \pm 11.4$ & $24.2 \pm 12.2$ & $30.2 \pm 11.0$ & $25.9 \pm 11.3$ & $29.6 \pm 10.9$ & 0.11 \\
\hline STICSA (cognitive), mean \pm SD & $24.2 \pm 7.2$ & $22.8 \pm 8.1$ & $25.3 \pm 7.3$ & $22.9 \pm 6.8$ & $25.9 \pm 6.7$ & 0.20 \\
\hline STICSA (somatic), mean \pm SD & $20.3 \pm 5.9$ & $20.2 \pm 6.7$ & $20.7 \pm 6.3$ & $19.7 \pm 4.8$ & $20.5 \pm 6.1$ & 0.90 \\
\hline PSQI (sleep quality), mean \pm SD & $13.4 \pm 3.9$ & $12.0 \pm 3.8$ & $13.9 \pm 3.8$ & $12.6 \pm 4.0$ & $15.0 \pm 3.3$ & $0.01 *$ \\
\hline On disability for PTSD/MH, $\%$ & 36.1 & 15.6 & 35.0 & 37.5 & 56.3 & $0.01 *$ \\
\hline
\end{tabular}




\begin{tabular}{|c|c|c|c|c|c|c|}
\hline Sexual trauma & 10.1 & 12.1 & 17.5 & 2.4 & 9.1 & 0.15 \\
\hline Physical assault/homicide of civilian & 16.9 & 18.2 & 17.5 & 11.9 & 21.2 & 0.75 \\
\hline Combat-related activity & 81.8 & 73.3 & 73.7 & 90.5 & 87.9 & 0.11 \\
\hline Witness death/execution & 71.6 & 66.7 & 67.5 & 73.8 & 78.8 & 0.64 \\
\hline $5+$ traumas/major injuries & 54.6 & 50.0 & 51.3 & 52.6 & 65.6 & 0.56 \\
\hline Trauma for $11+$ years, $\%$ & 53.8 & 65.6 & 55.0 & 53.7 & 40.6 & 0.26 \\
\hline \multicolumn{7}{|l|}{ Current medications, $\%$} \\
\hline Antidepressant & 46.0 & 12.1 & 77.5 & 38.1 & 51.5 & $<.01 *$ \\
\hline Antianxiety & 21.6 & 3.0 & 32.5 & 11.9 & 39.4 & $0.01 *$ \\
\hline Sleep & 20.3 & 0.0 & 22.5 & 14.3 & 45.5 & $<.01 *$ \\
\hline Antipsychotics & 12.2 & 3.0 & 12.5 & 9.5 & 24.2 & 0.06 \\
\hline Pain & 33.8 & 15.2 & 37.5 & 42.9 & 36.4 & 0.07 \\
\hline Treatment completion rate, $\%$ & 71.6 & 54.6 & 77.5 & 76.2 & 75.8 & 0.11 \\
\hline Total ART sessions, mean \pm SD & $3.5 \pm 1.4$ & $3.0 \pm 1.5$ & $3.6 \pm 1.3$ & $3.5 \pm 1.4$ & $3.7 \pm 1.5$ & 0.19 \\
\hline
\end{tabular}

PTSD: post-traumatic stress disorder; PCL-M: PTSD Checklist; CES-D: Center for Epidemiologic Depression Scale; STICSA: State-Trait Inventory for Cognitive and Somatic Anxiety; PSQI: Pittsburgh Sleep Quality Index; MH: mental health; SD: standard deviation; ART: Accelerated Resolution Therapy. *Significant difference at $p<.05$. 
Table 2. Symptom Treatment Response with Accelerated Resolution Therapy (ART) by Types of Prior History of PTSD Treatment (Classification \#1)

\section{Types of Prior History of PTSD Treatment}

Treatment-naïve Medication

Other Psychotherapy

First-line Psychotherapy

p-Value

$(\mathrm{B} / \mathrm{T})^{\mathrm{a}}$

Symptom measure

Diff. $\quad 95 \%$ CI.

ES

Diff. $\quad 95 \%$ C.I.

ES

Diff. $\quad 95 \%$ C.I.

ES

Diff. $\quad 95 \%$ C.I.

ES

Post-treatment vs. Pre-treatment (Treatment completion rate: $71.6 \%$ )

$\mathrm{n}=18 \quad \mathrm{n}=31 \quad \mathrm{n}=32$

PCL-M (PTSD checklist)

CES-D (depression)

, $-16.7-1.48-15.4$

$-20.4,-10.3-1.11$

$\mathrm{n}=32$
-192

$-14.6$

$-11.6$

$-15.9,-7.2-1.00$

$-12.7$

$-25.9,-12.4-1.03$

$\mathrm{n}=25$

Brief Symptom Inventory

$-17.1$

$-21.7,-7.4$

$-1.02$

$-16.7,-8.6$

$-1.12-11.5$

STICSA (anxiety)

$-9.8$

$-13.9,-5.6$

$-1.09$

$-14.6$

$-19.7,-9.6$

$-1.12$

$-11.5$

$-9.3,-4.9 \quad-1.19$

$-6.7$

$-9.6,-3.7$

$-0.81 \quad-10.2$

$\begin{array}{llll}-4.9 & -7.1,-2.6 & -1.25 & -1.7\end{array}$

$-0.51$

$-2.5-4.0$

$-0.65$

$-5.2$

$-0.61$

Follow-up vs. Pre-treatment (Follow-up rate: $51.9 \%$ )

PSQI (sleep quality)

$\mathrm{n}=8 \quad \mathrm{n}=15$

\section{PCL-M (PTSD checklist)}

CES-D (depression)

Brief Symptom Inventory

STICSA (anxiety)

$-28.3$

$-29.2,-6.5 \quad-1.32 \quad-8.9$

$-16.7,-3.0$

$-17.6,-0.2$

$-17.9,-1.2$

$-12.0$

$-34.1,-14.8 \quad-2.11 \quad-9.6$

$-17.9,-1.2$
-7.0

$-0.80$

$\mathrm{n}=16$

$-4.0,-1.0$

$-3.7,4.5$

$-0.57$

$-10.8-21.8,0.1$

$\mathrm{n}=16$

STICSA (somatic)

$\begin{array}{llll}-6.6 & -12.5,-0.8 & -0.95 & 0.4\end{array}$

$-4.3,1.1$

$-0.64$

$-5.0 \quad-12.9,2.8$

$-0.53$

$-21.4$

$-0.36-8.2$

$-0.36$

$-13.8$

$-15.8,3.1$

$-0.24$

$-6.2$

$-2.0$

$-6.4,2.4$

$-0.09 \quad-2.6$

$\begin{array}{lll}0.05 & -0.5 & -3.4,2.4 \\ -0.36 & -0.2 & -2.0,1.6\end{array}$

$-0.07 \quad-2.8$

\section{$-29.4,-18.8-1.88$}

$0.02 *$

$-16.0,-7.0 \quad-1.06$

0.59

$-22.3,-13.0-1.57$

0.24

PSQI (sleep quality)

$-5.3 \quad-10.2,-0.3 \quad-0.89 \quad-1.6$

$-5.8,0.2$

$-28.9,-14.0 \quad-1.53$

$-0.86$

0.49

PTSD: post-traumatic stress disorder; PCL-M: PTSD Checklist; CES-D: Center for Epidemiologic Depression Scale; STICSA: State-Trait

Inventory for Cognitive and Somatic Anxiety; MH: mental health; SD: standard deviation. ES(W/I): within-group effect size comparing mean scores before and after treatment with ART. ${ }^{a} \mathrm{~B} / \mathrm{T}$ : between-group comparison of treatment response adjusted for baseline value of the symptom measure, PCL-M, PSQI, disability, antidepressant, antianxiety and sleep medication. *Significant difference at $p<.05$. 
Table 3. Demographic and Clinical Characteristics of Study Participants by Prior History of PTSD Treatment (Classification \#2)

\begin{tabular}{|c|c|c|c|c|c|c|}
\hline \multirow[b]{2}{*}{ Characteristics } & \multirow[b]{2}{*}{$\begin{array}{c}\text { All } \\
(n=198)\end{array}$} & \multicolumn{4}{|c|}{ Prior History of PTSD Treatment } & \multirow[b]{2}{*}{ p-Value } \\
\hline & & $\begin{array}{l}\text { Treatment- } \\
\text { naïve }(n=50)\end{array}$ & $\begin{array}{l}\text { Medication } \\
\quad(n=43)\end{array}$ & $\begin{array}{l}\text { Psychotherapy } \\
\quad(n=25)\end{array}$ & $\begin{array}{c}\text { Psychotherapy } \\
\text { +Medication } \\
(\mathrm{n}=80)\end{array}$ & \\
\hline \multicolumn{7}{|l|}{ Demographic characteristics } \\
\hline Age in years, mean $\pm \mathrm{SD}$ & $43.4 \pm 13.2$ & $45.5 \pm 14.5$ & $44.8 \pm 13.0$ & $40.3 \pm 10.4$ & $42.2 \pm 13.1$ & 0.29 \\
\hline Male gender, $\%$ & 91.4 & 94.0 & 90.7 & 100.0 & 87.5 & 0.22 \\
\hline Race, $\%$ & & & & & & 0.91 \\
\hline White & 84.2 & 80.0 & 83.3 & 88.0 & 86.1 & \\
\hline Black & 11.6 & 14.0 & 14.3 & 8.0 & 11.4 & \\
\hline Other & 3.9 & 6.0 & 2.4 & 4.0 & 2.5 & \\
\hline Years of education, mean \pm SD & $14.6 \pm 2.7$ & $14.7 \pm 3.2$ & $14.4 \pm 2.9$ & $14.6 \pm 2.2$ & $14.7 \pm 2.3$ & 0.92 \\
\hline Current military status, $\%$ & & & & & & 0.44 \\
\hline Active duty & 8.1 & 12.2 & 9.3 & 12.0 & 3.8 & \\
\hline Reservist & 8.1 & 12.2 & 4.7 & 8.0 & 7.5 & \\
\hline Discharged/veteran & 83.8 & 75.5 & 86.1 & 80.0 & 88.8 & \\
\hline Four or more overseas tour, $\%$ & 27.3 & 24.4 & 23.1 & 37.5 & 27.9 & 0.61 \\
\hline Branch of service, $\%$ & & & & & & 0.75 \\
\hline Army & 57.6 & 44.0 & 60.5 & 60.0 & 63.8 & \\
\hline Navy & 14.7 & 22.0 & 14.0 & 8.0 & 12.5 & \\
\hline Marine Corps & 12.6 & 12.0 & 14.0 & 16.0 & 11.3 & \\
\hline Air force & 10.1 & 16.0 & 7.0 & 12.0 & 7.5 & \\
\hline National guard & 5.1 & 6.0 & 4.7 & 4.0 & 5.0 & \\
\hline \multicolumn{7}{|l|}{ Clinical characteristics } \\
\hline PCL-M (PTSD checklist), mean \pm SD & $58.2 \pm 14.0$ & $52.2 \pm 15.0$ & $58.2 \pm 12.0$ & $59.2 \pm 14.8$ & $61.7 \pm 13.0$ & $0.01 *$ \\
\hline Brief Symptom Inventory, mean \pm SD & $27.9 \pm 14.4$ & $23.2 \pm 14.8$ & $27.4 \pm 12.9$ & $27.0 \pm 15.1$ & $31.3 \pm 14.1$ & $0.03 *$ \\
\hline CES-D (depression), mean $\pm \mathrm{SD}$ & $27.3 \pm 11.9$ & $22.2 \pm 11.6$ & $29.5 \pm 11.3$ & $27.5 \pm 12.7$ & $29.0 \pm 11.5$ & $0.01 *$ \\
\hline STICSA (cognitive), mean \pm SD & $24.0 \pm 7.4$ & $21.8 \pm 7.7$ & $24.5 \pm 7.6$ & $25.0 \pm 7.1$ & $24.7 \pm 7.1$ & 0.17 \\
\hline STICSA (somatic), mean \pm SD & $20.1 \pm 6.1$ & $19.5 \pm 6.2$ & $20.2 \pm 6.3$ & $20.0 \pm 6.7$ & $20.4 \pm 5.8$ & 0.89 \\
\hline PSQI (sleep quality), mean \pm SD & $13.2 \pm 4.0$ & $11.7 \pm 4.1$ & $13.8 \pm 3.7$ & $13.6 \pm 3.8$ & $13.6 \pm 4.0$ & 0.05 \\
\hline On disability for PTSD/MH, \% & 37.1 & 14.3 & 34.9 & 36.0 & 53.3 & $<.01 *$ \\
\hline
\end{tabular}


Previous trauma history, \%

\begin{tabular}{|c|c|c|c|c|c|c|}
\hline Sexual trauma & 11.7 & 8.0 & 16.3 & 4.2 & 13.8 & 0.36 \\
\hline $\begin{array}{l}\text { Physical assault/homicide of } \\
\text { ian }\end{array}$ & 16.8 & 14.0 & 18.6 & 16.7 & 17.5 & 0.94 \\
\hline Combat-related activity & 84.4 & 78.7 & 75.6 & 91.7 & 90.0 & 0.09 \\
\hline Witness death/execution & 72.1 & 70.0 & 69.8 & 75.0 & 73.8 & 0.93 \\
\hline $5+$ traumas/major injuries & 52.9 & 51.0 & 52.4 & 56.5 & 53.3 & 0.98 \\
\hline rauma for $11+$ years, $\%$ & 52.8 & 65.3 & 51.2 & 40.0 & 50.0 & 0.17 \\
\hline \multicolumn{7}{|l|}{ urrent medications, $\%$} \\
\hline Antidepressant & 43.4 & 10.0 & 76.7 & 4.0 & 58.8 & $<.01^{*}$ \\
\hline Antianxiety & 20.2 & 4.0 & 30.2 & 8.0 & 28.8 & $<.01 *$ \\
\hline Sleep medication & 18.7 & 2.0 & 20.9 & 12.0 & 30.0 & $<.01 *$ \\
\hline Antipsychotic & 9.6 & 2.0 & 11.6 & 12.0 & 12.5 & 0.21 \\
\hline Pain reduction & 30.8 & 16.0 & 34.9 & 8.0 & 45.0 & $<.01^{*}$ \\
\hline atment completion rate, $\%$ & 77.3 & 68.0 & 79.1 & 84.0 & 80.0 & 0.32 \\
\hline al ART sessions, mean $\pm \mathrm{SD}$ & $3.5 \pm 1.3$ & $3.2 \pm 1.4$ & $3.7 \pm 1.3$ & $3.4 \pm 1.3$ & $3.7 \pm 1.3$ & 0.25 \\
\hline
\end{tabular}

Total ART sessions, mean \pm SD

$3.5 \pm 1.3 \quad 3.2 \pm 1.4 \quad 3.7 \pm 1.3$

$3.4 \pm 1.3$

PTSD: post-traumatic stress disorder; PCL-M: PTSD Checklist; BSI: Brief Symptom Inventory; CES-D: Center for Epidemiologic Depression Scale; STICSA: State-Trait Inventory for Cognitive and Somatic Anxiety; PSQI: Pittsburgh Sleep Quality Index; MH: mental health; SD: standard deviation; ART: Accelerated Resolution Therapy. *Significant difference at $p<.05$. 
Table 4. Symptom Treatment Response with Accelerated Resolution Therapy (ART) by Prior History of PTSD Treatment (Classification \#2)

\begin{tabular}{|c|c|c|c|c|c|c|c|c|c|c|c|c|c|}
\hline \multirow[b]{3}{*}{$\begin{array}{l}\text { Symptom } \\
\text { measure }\end{array}$} & \multicolumn{12}{|c|}{ Prior History of PTSD Treatment } & \multirow[b]{3}{*}{$\begin{array}{l}p \text {-Value } \\
(B / T)^{a}\end{array}$} \\
\hline & \multicolumn{2}{|c|}{ Treatment-naïve } & \multicolumn{3}{|c|}{ Medication } & \multicolumn{3}{|c|}{ Psychotherapy } & \multirow[b]{2}{*}{$\begin{array}{l}\mathrm{ES} \\
(\mathrm{W} / \mathrm{I})\end{array}$} & \multicolumn{3}{|c|}{ Psychotherapy+ Medication } & \\
\hline & Diff. & $95 \% \mathrm{CI}$. & $\begin{array}{l}\mathrm{ES} \\
(\mathrm{W} / \mathrm{I})\end{array}$ & Diff. & 95\% C.I. & $\begin{array}{l}\mathrm{ES} \\
(\mathrm{W} / \mathrm{I})\end{array}$ & Diff. & 95\% C.I. & & Diff. & 95\% C.I. & $\begin{array}{l}\mathrm{ES} \\
(\mathrm{W} / \mathrm{I})\end{array}$ & \\
\hline & \multicolumn{12}{|c|}{ Post-treatment vs. Pre-treatment (Treatment completion rate: $77.3 \%$ ) } & \\
\hline & $\mathrm{n}=34$ & & & $\mathrm{n}=34$ & & & $\mathrm{n}=21$ & & & $\mathrm{n}=64$ & & & \\
\hline $\begin{array}{l}\text { PCL-M } \\
\text { (PTSD } \\
\text { checklist) }\end{array}$ & -20.6 & $-25.8,-15.4$ & -1.39 & -16.5 & $-21.3,-11.7$ & -1.20 & -15.5 & $-23.7,-7.3$ & -0.86 & -20.2 & $-24.0,-16.3$ & -1.31 & 0.19 \\
\hline $\begin{array}{l}\text { CES-D } \\
\text { (depression) } \\
\text { Brief }\end{array}$ & -12.5 & $-16.6,-8.4$ & -1.07 & -12.2 & $-16.3,-8.1$ & -1.05 & -12.9 & $-17.6,-8.3$ & -1.27 & -12.0 & $-14.9,-9.1$ & -1.03 & 0.56 \\
\hline $\begin{array}{l}\text { Symptom } \\
\text { Inventory }\end{array}$ & -15.4 & $-20.3,-10.4$ & -1.08 & -13.8 & $-18.1,-9.4$ & -1.10 & -13.6 & $-19.0,-8.2$ & -1.18 & -15.8 & $-19.1,-12.6$ & -1.20 & 0.40 \\
\hline $\begin{array}{l}\text { STICSA } \\
\text { (anxiety) }\end{array}$ & -8.0 & $-10.6,-5.4$ & -1.09 & -6.9 & $-9.0,-4.9$ & -1.19 & -6.4 & $-10.5,-2.4$ & -0.72 & -8.1 & $-9.8 .-6.3$ & -1.16 & 0.06 \\
\hline $\begin{array}{l}\text { STICSA } \\
\text { (somatic) }\end{array}$ & -5.1 & $-7.1,-3.1$ & -0.87 & -3.4 & $-5.3,-1.5$ & -0.63 & -3.6 & $-6.8,-0.3$ & -0.50 & -4.2 & $-5.7,-2.8$ & -0.72 & 0.16 \\
\hline \multirow[t]{3}{*}{$\begin{array}{l}\text { PSQI (sleep } \\
\text { quality) }\end{array}$} & -3.8 & $-5.2,-2.4$ & -1.06 & -1.8 & $-3.1,-0.4$ & -0.50 & -3.2 & $-4.9,-1.5$ & -0.90 & -2.6 & $-3.9,-1.4$ & -0.53 & 0.25 \\
\hline & \multicolumn{12}{|c|}{ Follow-up vs. Pre-treatment (Follow-up rate: $60.8 \%$ ) } & \\
\hline & $\mathrm{n}=23$ & & & $\mathrm{n}=17$ & & & $\mathrm{n}=12$ & & & $\mathrm{n}=41$ & & & \\
\hline $\begin{array}{l}\text { PCL-M } \\
\text { (PTSD } \\
\text { checklist) }\end{array}$ & -24.9 & $-32.0,-17.7$ & -1.53 & -11.1 & $-17.3,-4.9$ & -0.92 & -21.4 & $-33.8,-8.9$ & -1.09 & -17.5 & $-22.4,-12.6$ & -1.13 & 0.50 \\
\hline $\begin{array}{l}\text { CES-D } \\
\text { (depression) } \\
\text { Brief }\end{array}$ & -13.3 & $-18.5,-8.1$ & -1.11 & -8.7 & $-16.3,-1.1$ & -0.59 & -12.2 & $-20.6,-3.8$ & -0.92 & -8.1 & $-12.0,-4.1$ & -0.65 & 0.78 \\
\hline $\begin{array}{l}\text { Symptom } \\
\text { Inventory }\end{array}$ & -19.7 & $-25.9,-13.4$ & -1.39 & -9.2 & $-16.5,-1.8$ & -0.64 & -17.3 & $-26.5,-8.1$ & -1.20 & -11.6 & $-16.6,-6.6$ & -0.74 & 0.83 \\
\hline $\begin{array}{l}\text { STICSA } \\
\text { (anxiety) }\end{array}$ & -9.2 & $-12.9,-5.6$ & -1.12 & -2.5 & $-6.6,-1.6$ & -0.32 & -6.4 & $-10.9,-1.9$ & -0.91 & -4.7 & $-7.0,-2.4$ & -0.65 & 0.48 \\
\hline $\begin{array}{l}\text { STICSA } \\
\text { (somatic) }\end{array}$ & -5.3 & $-7.8,-2.8$ & -0.94 & 0.3 & $-3.3,3.8$ & 0.04 & -6.3 & $-10.2,-2.5$ & -1.04 & -1.8 & $-3.6,0.0$ & -0.32 & 0.25 \\
\hline
\end{tabular}


PSQI (sleep

$-3.8$

$-6.0,-1.6$

$-0.79$

$-2.0 \quad-4.6,0.6$

$-0.44$

$-2.5 \quad-5.4,0.4$

$-0.57 \quad-1.5 \quad-3.0,0.1$

$-0.33$

0.53

PTSD: post-traumatic stress disorder; PCL-M: PTSD Checklist; BSI: Brief Symptom Inventory; CES-D: Center for Epidemiologic Depression Scale; STICSA: State-Trait Inventory for Cognitive and Somatic Anxiety; MH: mental health; SD: standard deviation. ES(W/I): within-group effect size comparing mean scores before and after treatment with ART. ${ }^{\mathrm{B}} \mathrm{B} / \mathrm{T}$ : between-group comparison of treatment response adjusted for baseline value of the symptom measure, PCL-M, Brief symptom inventory, CES-D, disability, antidepressant, antianxiety, medication use for sleep and pain 